\title{
Changes in Atlantic cod (Gadus morhua L.) sperm quality during the spawning season
}

\author{
C. Rouxel ${ }^{1,{ }^{*}}$, M. Suquet ${ }^{2}$, J. Cosson ${ }^{3}$, A. Severe ${ }^{2}$, L. Quemener ${ }^{2}$ and C. Fauvel ${ }^{4}$
}

${ }^{1}$ IFREMER, Laboratoire PBA, Nantes, France

2 IFREMER, Laboratoire ARN, Brest, France

${ }^{3}$ CNRS, Laboratoire de Biologie Cellulaire, 06230 Villefranche/Mer, France

${ }^{4}$ IFREMER, LRPM, 34250 Palavas, France

*: Corresponding author : C. Rouxel, email address : catherine.rouxel@ifremer.fr

\begin{abstract}
:
The biology of cod reproduction is well described in the scientific literature. However, sperm biology and spermatozoa management are poorly studied in this species. Because of its recent farming expansion, a better knowledge of cod gametes is becoming especially useful. This work aimed at establishing tools to study sperm biology in cod, and also investigated the existence of changes in cod sperm quality during the spawning period. We showed that sperm concentration could be assessed using spectrophotometry at $260 \mathrm{~nm}$. Sperm motility significantly decreased after a 168-h storage at 4 degrees C. A 1:9 dilution of sperm in a non-activating medium (1/3 seawater and 2/3 freshwater, osmotic pressure: $360 \mathrm{mOsm} \mathrm{kg}(-1)$ ) improved sperm storage. Sperm concentration, sperm velocity and storage capacity at 4 degrees $C$ peaked during the medium period of the spawning season and then decreased to values close to those observed at the beginning of the reproductive period. The measured values of osmotic pressure, $\mathrm{pH}$, protein, $\mathrm{Na}+\mathrm{Cl}$ - and $\mathrm{Ca} 2+$ concentrations of the seminal fluid were modified along the spawning period. Cell damage was noted at the end of the spawning period: local blebs were observed on the flagellum but also loops at its distal part. On the other hand, spermatocrit did not vary with the sampling date. In conclusion, cod sperm quality is modified during the spawning period, the highest-quality samples being collected during the medium part of this season.
\end{abstract}

Keywords: Gadus morhua, cod, sperm, ageing, quality, spermatozoa 


\section{Introduction}

Cod (Gadus morhua) farming recently expanded because of a dramatic fall in wild catches, a rise in selling prices, a good knowledge of its biology, a high capacity of its flesh to be transformed and market demand far exceeding the supply. A production potential of 500,000 tonnes of cod per year has been suggested in Norway, surpassing wild catches (Adoff, Skejennum \& Engelsen 2002). Cod reproduction is well known in the wild as well as in captivity conditions. However, the knowledge of sperm biology and gametes management techniques remains limited in this species (Kjorsvik \& Tanem 2005).

Intratesticular aging of sperm has been reported in many fish species and it affects sperm quality as the reproductive period progresses (Rana 1995). At the end of the spawning period of seabass (Dicentrarchus labrax), spermatozoa concentration, intracellular ATP content and adenylate energy charge, percentage of motile cells, fertilizing capacity, short term storage and freezing abilities were significantly reduced compared to the values observed at the beginning of the reproductive season (Dreanno, Suquet, Fauvel, Le Coz, Dorange, Quemener, \& Billard 1999). An aging phenomenon of sperm was also reported in Atlantic halibut (Hippoglossus hippoglossus), altering sperm quality at the end of the milting period (Vermeirssen, De Quero, Shields, Norberg, Kime \& Scott 2004). In turbot (Psetta maxima; Suquet, Dreanno, Dorange, Normant, Quemener, Gaignon \& Billard 1998) end of spawning season leads to spermatozoa with damaged plasma membrane.

Changes of cod sperm quality as a function of the spawning season were partly reported by Rakitin, Ferguson \& Trippel (1999), showing an increase in spermatocrit and sperm number. Furthermore, sperm collected at the end of the spawning season presented a reduced post-thaw motility compared to that collected two weeks after the earliest part of spawning season (Rideout, Trippel \& Litvak 2004). This paper aimed at settling tools useful to study sperm biology in cod. Furthermore, it investigated the changes of cod sperm quality during the spawning period of the females.

\section{Materials and methods}

\subsection{Broodstock management and sperm sampling}

Forty cod fish initially collected in the wild were hatchery reared (male mean weight $\pm S D$ : $2.6 \pm 0.6 \mathrm{~kg}$ ) and were maintained in two $15 \mathrm{~m}^{3}$ indoor tanks and subjected to the natural variations of photoperiod (L/D from $8 \mathrm{~h} 30 / 15 \mathrm{~h} 30$ to $16 \mathrm{~h} / 8 \mathrm{~h})$ and to a chilled cycle of temperature $\left(7-14^{\circ} \mathrm{C}\right)$. Sea water renewal was $30 \%$ tank volume. $\mathrm{h}^{-1}$. Cod were fed ad libitum twice a week with fresh food (sardines and mackerels). In order to estimate the individual variations of sperm production, each male was tagged using magnetic marks inserted in operculum. After anaesthesia (phenoxyethanol, $200 \mathrm{~g} . \mathrm{I}^{-1}$ ), males were sampled at the beginning (January $13^{\text {th }}$ ), middle (February $22^{\text {th }}$ ) and end (March $15^{\text {th }}$ ) of the spawning period of the females. For each animal, $2.5 \mathrm{ml}$ of sperm were sampled by stripping ripe males from the anterior portion towards the urogenital pore. Faeces and urine were carefully discarded. Sperm was stored over ice until use.

\subsection{Experimental procedure}

Spermatozoa concentration was determined after dilution $(2 \mu \mathrm{l}$ sperm: $1998 \mu \mathrm{l}$ distilled water) by counting on Malassez cells and by spectrophotometry. Optical densities of successive sperm dilutions (3 males) in distilled water (from 1:250 to 1:4000) were assessed at 260nm (Uvikon 923). This wavelength corresponds to DNA optical absorption therefore allowing its concentration assessment and this was successfully used to estimate seabass spermatozoa concentration (Fauvel, Savoye, Dreanno, Cosson \& Suquet 1999) .

The storage capacity of sperm samples stored at $4^{\circ} \mathrm{C}$ during 24 and 96 hours without any dilution was estimated by determination of the percentage of motile cells. The percentage of motile spermatozoa was assessed using a two step procedure: $1^{\text {st }}-2.5 \mu \mathrm{l}$ sperm in $50 \mu \mathrm{l}$ of a non activating medium (1/3 
seawater and $2 / 3$ freshwater, osmotic pressure: $\left.360 \mathrm{mOsm} \cdot \mathrm{kg}^{-1}\right), 2^{\text {nd }}-2.5 \mu \mathrm{l}$ diluted sperm in $80 \mu \mathrm{l}$ of an activating medium (seawater+2\% BSA). Sperm motility was estimated at 10 seconds after activation by the same observer and at room temperature $\left(19 \pm 1^{\circ} \mathrm{C}\right)$ on a microscope glass slide using a $20 \mathrm{X}$ objective and a 10X ocular. Sperm velocity was measured on still frames of a video monitor from the length of the sperm tracks generated by use of the «trace» function (image accumulation set on 2 seconds) of a real time video enhancer (DVS-3000, Hamamatsu, Japan). Velocity was assessed on 30 spermatozoa for each male. Photographs were obtained using dark field microscopy with a 40X objective and a 10X ocular, a stroboscopic illumination (flash frequency $=150 \mathrm{~Hz}$ ) with a Nikon digital camera.

Seminal fluid samples were obtained after centrifugation at $4^{\circ} \mathrm{C}$ of semen at $8000 \mathrm{~g}$ for $10 \mathrm{~min}$. Osmotic pressure (ROEBLING) and pH (TACUSSEL, Minisis 8000) were immediately assessed. The supernatant (seminal fluid) was frozen and stored at $-20^{\circ} \mathrm{C}$ until analysis. Ions concentration was assessed with a SYNCHRON El-ise and total protein concentration was determined using the Lowry's method. Spermatocrit (\%) was determined after centrifugation at 10,000g for $10 \mathrm{~min}$.

\subsection{Statistics}

Data were expressed as mean \pm SD. Correlations between absorbance and sperm concentration or between spermatocrit and sperm concentration were evaluated by a linear regression calculation fitting. After angular transformation, data were compared using one or two way ANOVA. A repeated design was used to compare changes in sperm quality with time. Significant differences were determined using a Tukey a posteriori test.

\section{Results}

A highly significant correlation was observed between spermatozoa concentration determined by counting with Malassez glass slide and absorbance assessed at $260 \mathrm{~nm}\left(P<0.001, R^{2}=0.993\right.$; Fig. 1$)$. We also observed a significant correlation between spermatocrit and spermatozoa concentration estimated by spectrophotometry $\left(P<0.001, R^{2}=0.415\right.$; Fig. 2$)$. A significant decrease $(P<0.05)$ of the potential of sperm for motility was observed after $168 \mathrm{~h}$ storage at $4^{\circ} \mathrm{C}$ (Fig. 3). This decrease was significantly reduced in sperm samples diluted (1:9) in the non activating solution.

Significant changes of spermatozoa concentration during the spawning season were observed $(P<0.001$; Fig. 4) : an increase from the beginning to the middle part of the spawning period and then a decrease towards the end of the reproductive period was detected. The storage capacity at $4^{\circ} \mathrm{C}$, analysed by the percentage of motile cells, peaked during the medium part of the spawning period $(P<0.001 ;$ Fig. 5). On the other hand, no significant changes were recorded during the spawning period for spermatocrit (Fig. 6). Significantly $(P<0.001)$ higher values of sperm velocity were observed during the middle part of the spawning period (February: $156.4 \pm 8.2 \mu \mathrm{m}_{\mathrm{se}} \mathrm{se}^{-1}$ ), compared to the beginning (January: $86.5 \pm 15.2 \mu \mathrm{m} . \mathrm{sec}^{-1}$ ) or the end (March: $85.6 \pm 13.9 \mu \mathrm{m} . \mathrm{sec}^{-1}$; Fig. 7). Cell damage was observed on activated cod spermatozoa at the end of the spawning season (Fig. 8): flagella devoided of waves propagation, local blebs on the flagellum, loops at the distal tip of the flagellum and two regions of wave propagation on the flagellum.

Values of osmotic pressure, $\mathrm{pH}$, protein, $\mathrm{Na}^{+}, \mathrm{Cl}^{-}$and $\mathrm{Ca}^{2+}$ concentrations of the seminal fluid were significantly modified during the spawning period. On the other hand, $\mathrm{CO}_{2}$ content was not affected by the sampling date (Table I).

\section{Discussion}

According to results observed for seabass sperm (Fauvel, Savoye Dreanno, Cosson \& Suquet 1999), cod sperm concentration can be assessed by spectrophotometry, using a 1:1000 dilution in distilled water. On the other hand, a rather low correlation coefficient was observed between sperm density and spermatocrit. As it was reported in three freshwater fish species (Ciereszko \& Dabrowski 1993), there was no clear interface in capillary tubes between cod sperm pellet and seminal fluid supernatant, 
even when a high speed centrifugation was used, which makes the spermatocrit method poorly accurate. As a consequence, spectrophotometry must be used to assess sperm concentration in cod because it provides a simple, objective, accurate and rapid estimation.

Changes in cod sperm quality in relation with the sampling date were observed. Such changes were reported in some fish species (Rana 1995) but also in mammals (Thibault 1967) and amphibians (Cabada 1975). An aging phenomenon of fish sperm is suggested to be a consequence of a discontinuous gametogenesis: spermatozoa are released over a period of several month before a new spermatogenetic cycle is initiated. Since the spermiation period lasts several months, spermatozoa age towards the end of the reproductive period. In the case of seabass, drastic seasonal alterations of sperm quality were observed, leading to decrease most sperm features at the end of the reproductive period (Dreanno, Suquet, Fauvel, Le Coz, Dorange, Quemener \& Billard. 1999). A discontinuous spermatogenesis is suggested in this species (Zohar, Billard \& Weill 1984) and as a high gonadosomatic index (4\%) is observed at the peak of the spawning period this hypothesis is strengthened (Barnabé 1976). Cod spermatogenesis last three months and mature spermatozoa are observed several month before the spawning season of females. Furthermore, high maximum values of GSI were reported in cod males: mean 6.5 and as high as 12.5 (Burton, Penney \& Biddiscombe 1997) which were confirmed by Trippel \& Morgan (1994). Both observations suggest a discontinuous spermatogenesis in cod. However, cod and seabass spermatogenesis may differ since all germ cell stages can be present at the same time in the former species but not in the latter one (Zohar, Billad \& Weill 1984). Compared to seabass, this sustains the existence of moderate changes of cod sperm quality during the spawning period as observed in this work : sperm concentration, sperm velocity and storage capacity at $4^{\circ} \mathrm{C}$ increased during the first half of the spawning period and then decreased to values close to those observed at the beginning of the reproductive period.

In opposition to this work, Rakitin, Fergusson \& Trippel (1999) observed a continuous increase of cod sperm concentration. Such changes with time could depend on the age of the milters as reported in rainbow trout (Oncorhynchus mykiss; Chechun, Pantaleeva \& Samoded 1994). Seasonal modifications of sperm concentration also vary depending on fish species: a decrease was observed in seabass (Dreanno, Suquet, Fauvel, Le Coz, Dorange, Quemener \& Billard 1999; Fauvel, Savoye Dreanno, Cosson \& Suquet 1999) while an increase was recorded in turbot (Suquet, Dreanno, Dorange, Normant, Quemener, Gaignon \& Billard 1998).

Except for osmotic pressure (De Graaf \& Berlinsky 2004), the composition of cod seminal fluid was not reported in the scientific literature up to now. Significant changes during the spawning period of most cod seminal fluid features were observed in this work. Seasonal variations of seminal fluid composition were also reported in Atlantic salmon (Salmo salar; Aas, Refstie \& Gjerde 1991) and in seabream (Sparus aurata; Kara, Derbal \& Labed 1996). Protein content of cod seminal fluid (from 0.48 to 2.02

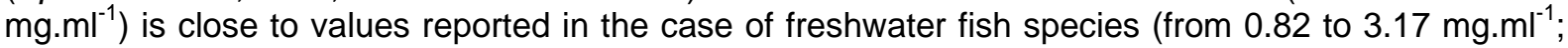
Ciereszko, Piros, Dabrowski, Kucharczyk, Uczyski, Dobosz \& Glogowski 1998) but lower than contents assessed in seabream (from 5.00 to $6.67 \mathrm{mg} \cdot \mathrm{ml}^{-1}$; Kara, Derbal \& Labed 1996) or turbot (from 9.8 to $16.6 \mathrm{mg}^{\mathrm{ml}}{ }^{-1 ;}$ Dreanno, Suquet, Desbruyères, Cosson, Le Delliou \& Billard 1998). Protein changes are of importance because of their protective role played for spermatozoa in many fish species (Billard 1982). In cod, addition of protein in activating medium avoids aggregation of swimming spermatozoa, suggesting their role in gamete protection. The decrease of protein content assessed at the end of cod spawning period could affect this protective role. The osmotic pressure of cod seminal fluid assessed in this work (332-407 mosml..$\left.^{-1}\right)$ is close to values previously reported in this species (314 mosml..$^{-1}$ ) by De Graaf \& Berlinsky (2004). Cod sperm motility could be triggered by dilution in glucose solutions presenting osmotic pressure higher than 700 mosml. ${ }^{-1}$ (Cosson unpublished result). This suggests that the low osmotic pressure of seminal fluid could prevent sperm motility in the genital tract. However, other factors such as $\mathrm{CO}_{2}$ or ionic strength could also be involved in the inhibition of cod sperm motility, as reported in turbot (Dreanno 1998). Nevertheless, $\mathrm{CO}_{2}$ does not directly stops motility of cod spermatozoa (Cosson unpublished result). Calcium concentration of cod seminal fluid is similar to values reported in seabream (from 1.73 to 3.97 mmol. $^{-1}$; Kara, Derbal \& Labed 1996). A decrease of calcium seminal fluid content was reported at the end of the spawning period in seabream which is not observed in cod.

A higher storage capacity at $4^{\circ} \mathrm{C}$ of cod sperm was observed during the medium period of the spawning season, compared to the beginning and the end. At the same temperature, storage capacity of seabass sperm decreased from $70 \mathrm{~h}$ at the beginning of the spawning season to only 30 minutes in the middle and end of this period (Billard, Dupont \& Barnabé 1977). Sperm velocity observed in the middle part of the reproductive period was close to values recorded by Rideout, Trippel \& Litvak (2004: $148.6 \pm 19.2 \mu \mathrm{m} . \mathrm{s}^{-1}$.). 
In conclusion, techniques used to store cod sperm at positive temperature and to estimate its sperm concentration were settled in this study. Changes of cod sperm quality during the reproductive period have been described: sperm concentration, the composition of the seminal fluid and storage capacities were modified from January to March. Highest quality sperm samples are collected during the medium part of the spawning period. Further results including fertilization capacity and nucleotide content are needed to confirm sperm quality changes in cod during the reproductive period.

\section{References}

Aas G.H., Refstie T. \& Gjerde B. (1991) Evaluation of milt quality of Atlantic salmon. Aquaculture 95, $125-132$.

Adoff G., Skjennum F.C. \& Engelsen R. (2002) Experience and prospects of Norwegian cod farming. Bulletin Aquaculture Association Canada 102, 8-11.

Barnabé G. (1976) Contribution à la connaissance de la biologie du loup, Dicentrarchus labrax L., Poisson Serranidae. Thesis, Montpellier, University of Languedoc, 426pp.

Billard R. (1982) Importance des protéines du liquide cœlomique sur la fertilité des gamètes chez la truite arc en ciel et possibilité de substitution. Bulletin Français de Pisciculture 284, 168-177.

Billard R., Dupont J. \& Barnabé G. (1977) Diminution de la motilité et de la durée de conservation du sperme de Dicentrarchus labrax L., (Poisson, téléostéen) pendant la période de spermiation. Aquaculture 11, 363-367.

Burton M.P.M., Penney R.M. \& Biddiscombe S. (1997) Time course of gametogenesis in Northwest Atlantic cod (Gadus morhua). Canadian Journal of Aquatic Sciences 54, 122-131.

Cabada M.O. (1975) Seasonal variations in the fertilizing capacity of Bufo arenarum (Amphibia anura) spermatozoa. Experientia 31, 174-175.

Chechun T.Y., Pantaleeva N.O. \& Samoded A.Y. (1994) Seasonal and age-related and quantitatives changes in sperm production in steelhead, Oncorhynchus mykiss. Journal of Ichthyology 34, 78-89.

Ciereszko A. \& Dabrowski K. (1993) Estimation of sperm concentration of rainbow trout, whitefish and yellow perch using a spectrophotometric technique. Aquaculture 109, 367-373.

Ciereszko A., Piros B., Dabrowski K., Kucharczyk D., Uczyski M.J., Dobosz S. \& Glogowski J. (1998) Serine proteinase inhibitors of seminal plasma of teleost fish: distribution of activity, electrophoretic profiles and relation to proteinase inhibitors of blood. Journal of Fish Biology 53, 1292-1305.

De Graaf J.D. \& Berlinsky D.L. (2004) Cryogenic and refrigerated storage of Atlantic cod (Gadus morhua) and haddock (Melanogrammus aeglefinus) spermatozoa. Aquaculture 234, 527-540.

Dreanno C. (1998) Régulation de la mobilité des spermatozoïdes de turbot (Psetta maxima) et de bar (Dicentrarchus labrax). Thesis, University Rennes 1, 102pp.

Dreanno C., Suquet M., Desbruyères E., Cosson J., Le Delliou H. \& Billard R. (1998) Effect of urine on semen quality in turbot (Psetta maxima). Aquaculture 169, 247-262.

Dreanno C., Suquet M., Fauvel C., Le Coz J.R., Dorange G., Quéméner L. \& Billard R. (1999) Effect of aging process on the quality of seabass (Dicentrarchus labrax) semen. Journal of Applied Ichthyology 15, 176-180.

Fauvel C., Savoye O., Dreanno C., Cosson J. \& Suquet M. (1999) Characteristics of sperm of captive seabass in relation to its fertilization potential. Journal of Fish Biology 54, 356-369.

Kara M.H., Derbal F. \& Labed S. (1996) Composition du liquide séminal de Sparus aurata au cours d'une saison de spermiation. Journal of Applied Ichthyology 12, 69-70.

Kjorsvik E. \& Tanem I. (2005) Cod (Gadus morhua) egg quality in commercial hatcheries. EAS, Special Publication 35, 479-480.

Rakitin A., Ferguson M.M. \& Trippel E. A. (1999) Spermatocrit and spermatozoa density in Atlantic cod (Gadus morhua): correlation and variation during the spawning period. Aquaculture 170, 349-358.

Rana K. (1995) Preservation of gametes. In: Management and egg and larval quality (eds. by N.R Bromage. \& R.J Roberts), pp. 53-76. Oxford: Blackwell Science.

Rideout R.M., Trippel E.A. \& Litvak M.K. (2004) The development of haddock and Atlantic cod sperm cryopreservation techniques and the effect of sperm age on cryopreservation success. Journal of Fish Biology 65, 299-311.

Suquet M., Dreanno C., Dorange G., Normant Y., Quemener L., Gaignon J.L. \& Billard R. (1998) The ageing phenomenon of turbot spermatozoa: effects on morphology, motility and concentration, intracellular ATP content, fertilization, and storage capacities. Journal of Fish Biology 52, 31-41.

Thibault C. (1967) Analyse comparée de la fécondation et de ses anomalies chez la brebis, la vache et la lapine. Annales Biologie Animale Biochimie Biophysique 7, 5-23. 
Trippel E.A. \& Morgan M.J. (1994) Age-specific paternal influences on reproductive success of Atlantic cod (Gadus morhua L.) of the Grand Banks, Newfoundland. ICES Marine Science Symposium 198, 414-422.

Vermeirssen E.L.M., De Quero C.M., Shields R.J., Norberg B., Kime D.E. \& Scott A.P. (2004) Fertility and motility of sperm from Atlantic halibut (Hippoglossus hippoglossus) in relation to dose and timing of gonadotropin-realasing hormone agonist implant. Aquaculture 230, 547-567.

Zohar Y., Billard R. \& Weill C. (1984) La reproduction de la daurade (Sparus aurata) et du bar (Dicentrarchus labrax): connaissance du cycle sexuel et contrôle de la gamétogenèse et de la ponte. In : L'Aquaculture du bar et des sparidés, (eds G. Barnabé \& R. Billard), pp. 3-24, Paris, INRA.

\section{Figures}

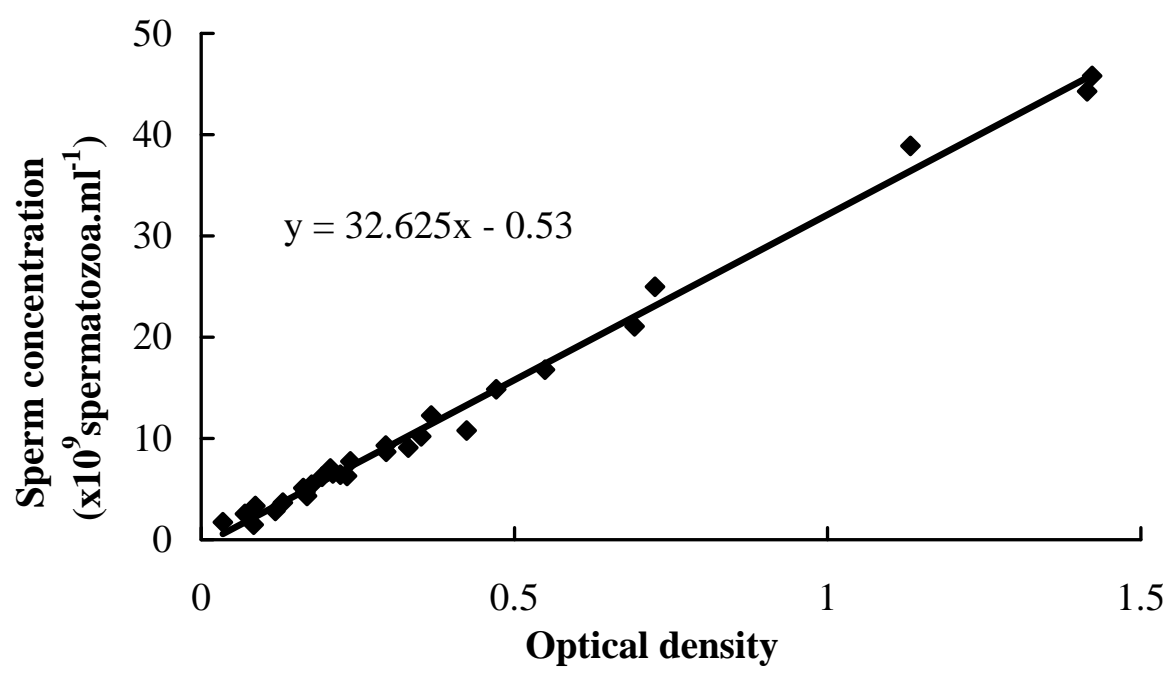

Fig. 1: Correlation between optical density observed at $260 \mathrm{~nm}$ and spermatozoa concentration assessed using Malassez cells ( $\mathrm{n}=3$ males and 30 samples).

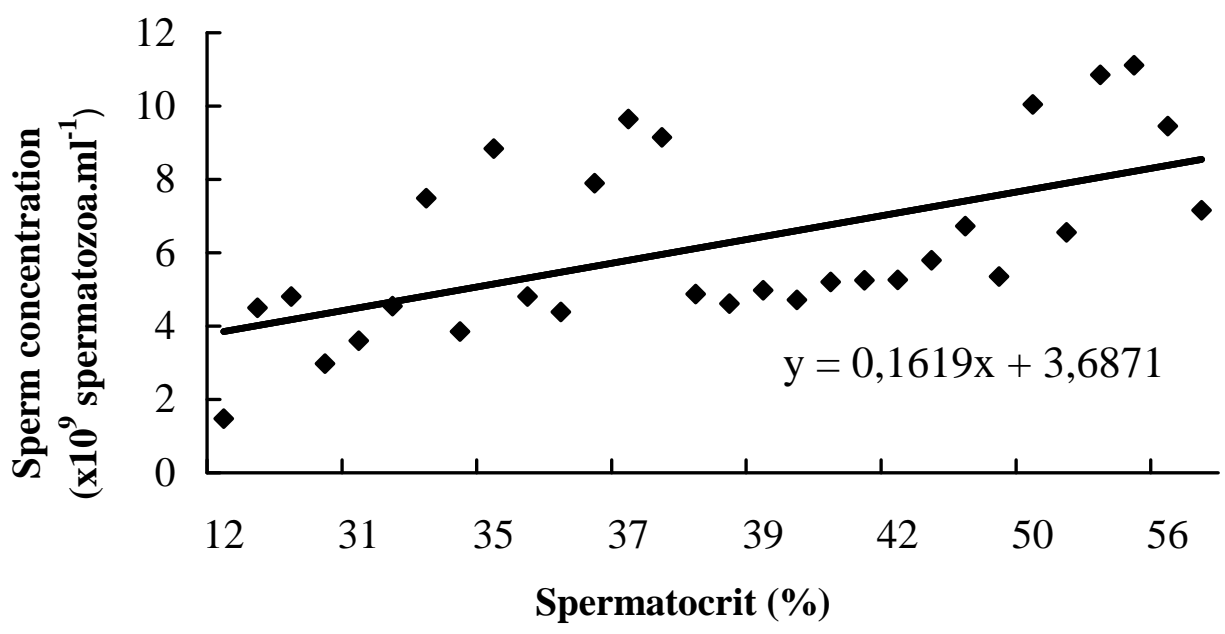

Fig. 2: Correlation between spermatocrit and sperm density observed at $260 \mathrm{~nm}(\mathrm{n}=10$ males and 30 samples). 


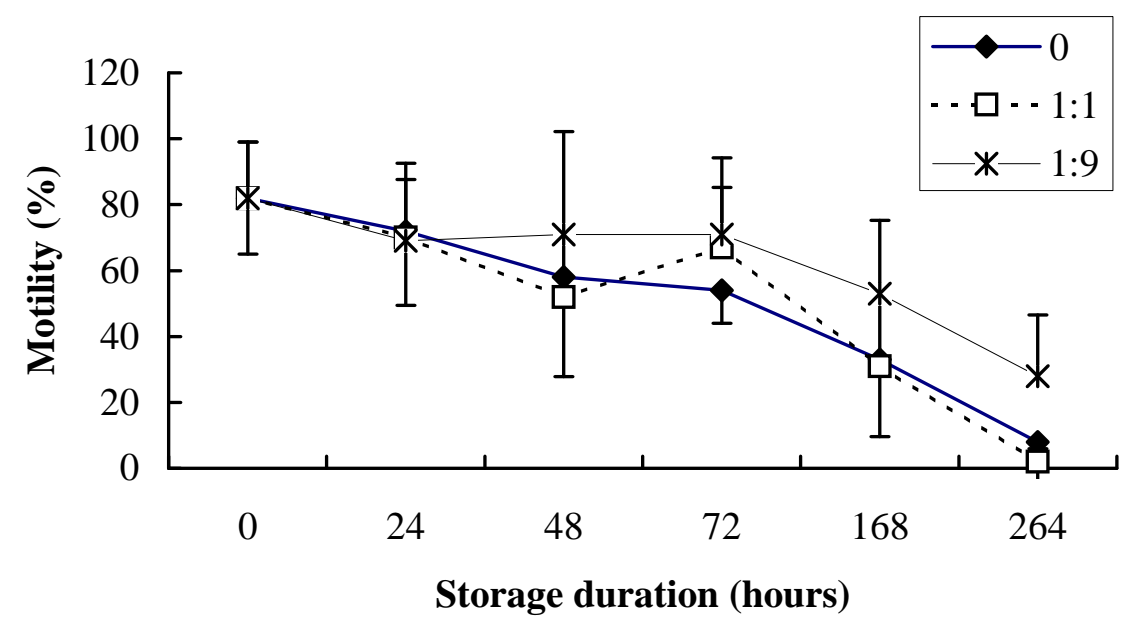

Fig. 3: Changes in the percentage of motile spermatozoa in relation with storage duration at $4^{\circ} \mathrm{C}$ and sperm dilution rate (sperm:medium) in a non activating medium ( $1 / 3$ seawater and $2 / 3$ freshwater) ( $n=6$ males).

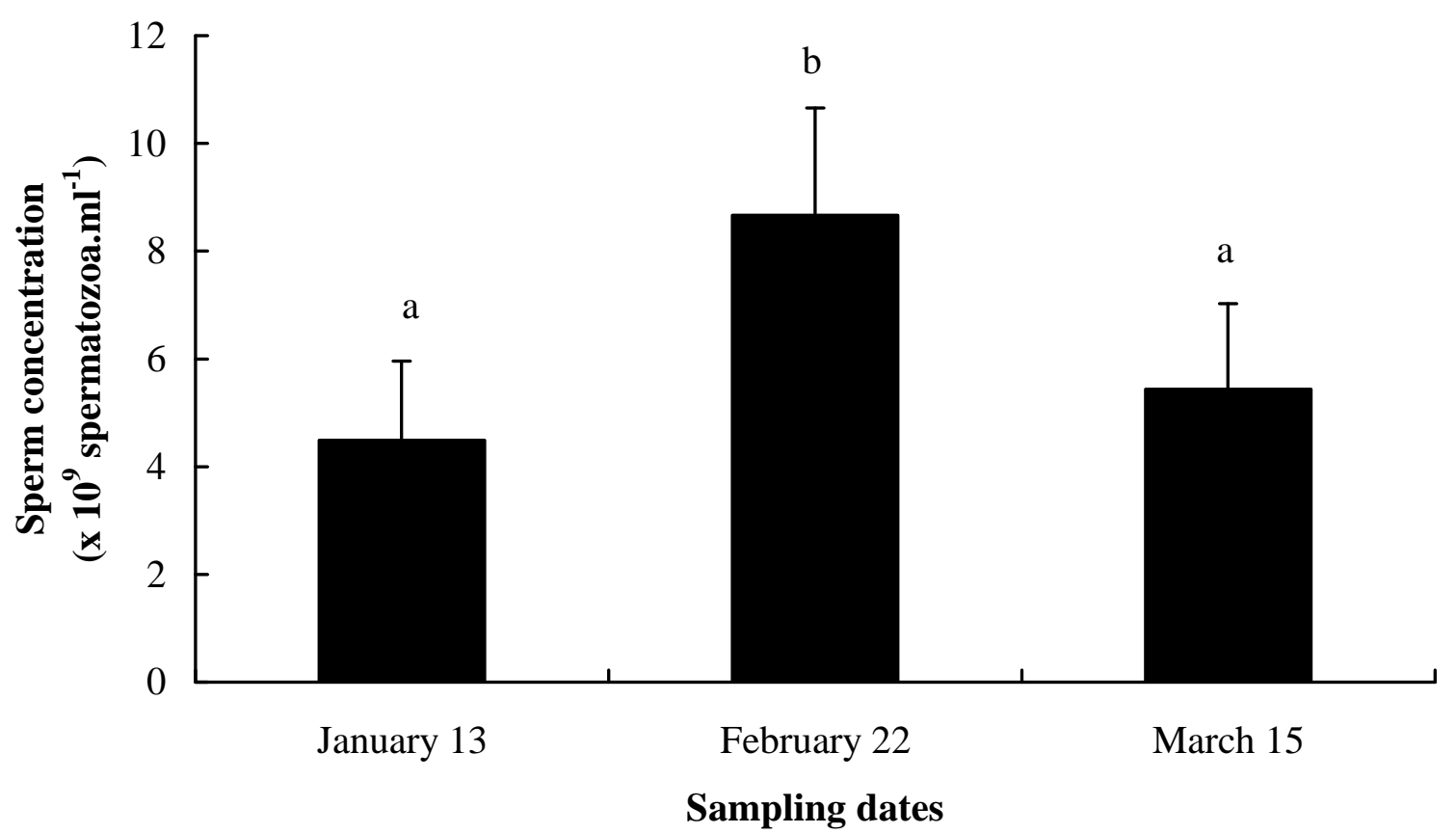

Fig. 4: Changes in sperm concentration during the spawning period (Different letters correspond to significantly different results, $n=10$ males). 


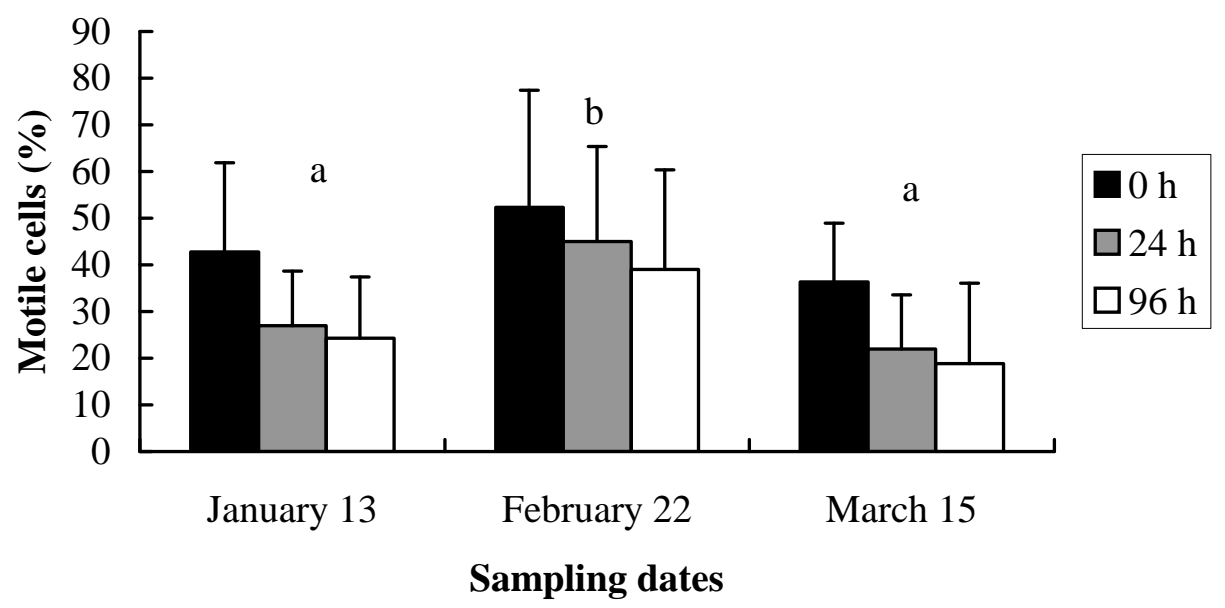

Fig. 5: Changes in undiluted sperm storage capacity at $4^{\circ} \mathrm{C}$ during the spawning period and for different storage durations $(0,24$ and $96 \mathrm{~h}$; different letters correspond to significantly different results, $\mathrm{n}=10$ males).

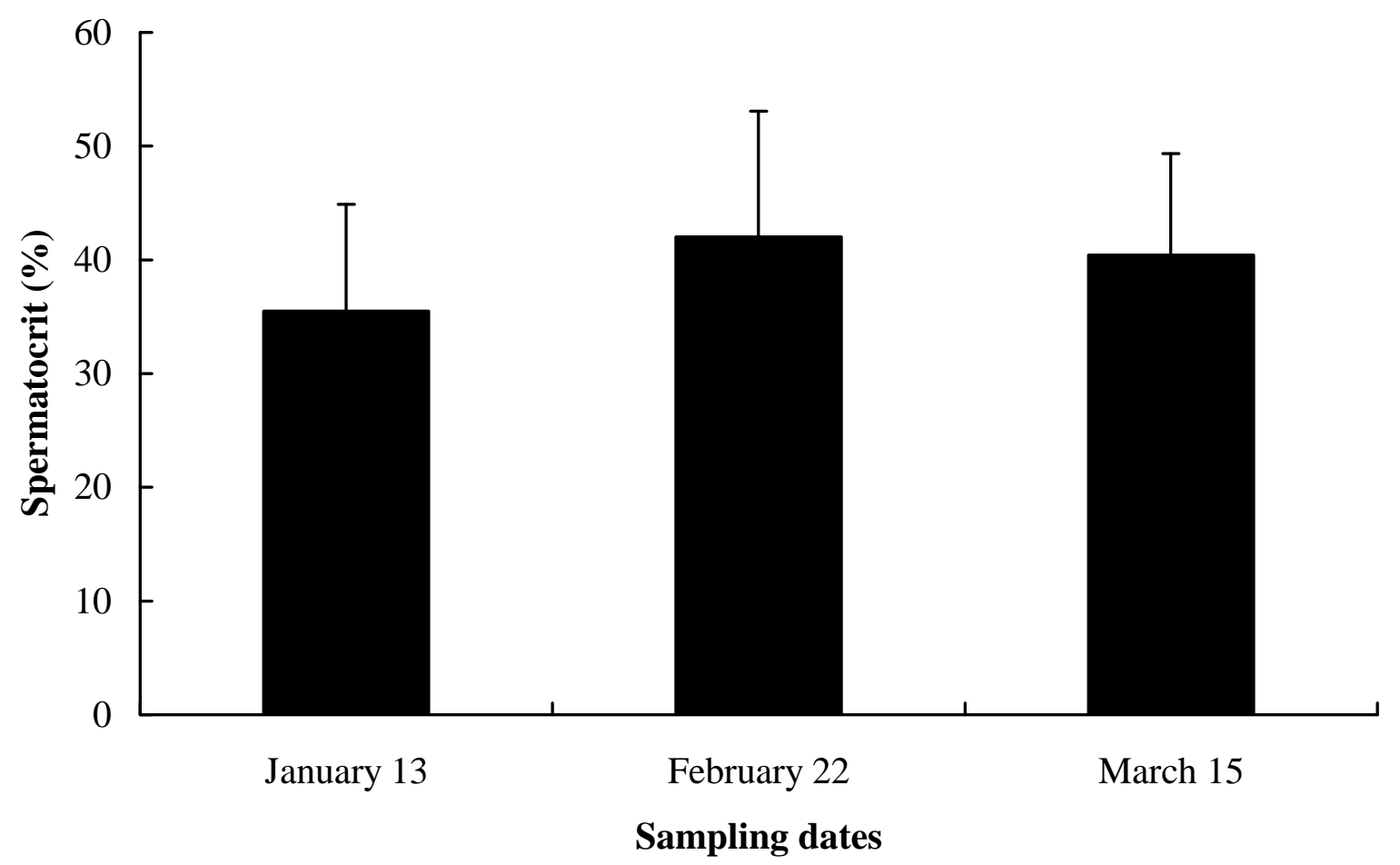

Fig. 6: Changes in spermatocrit during the spawning period ( $\mathrm{n}=10$ males). 


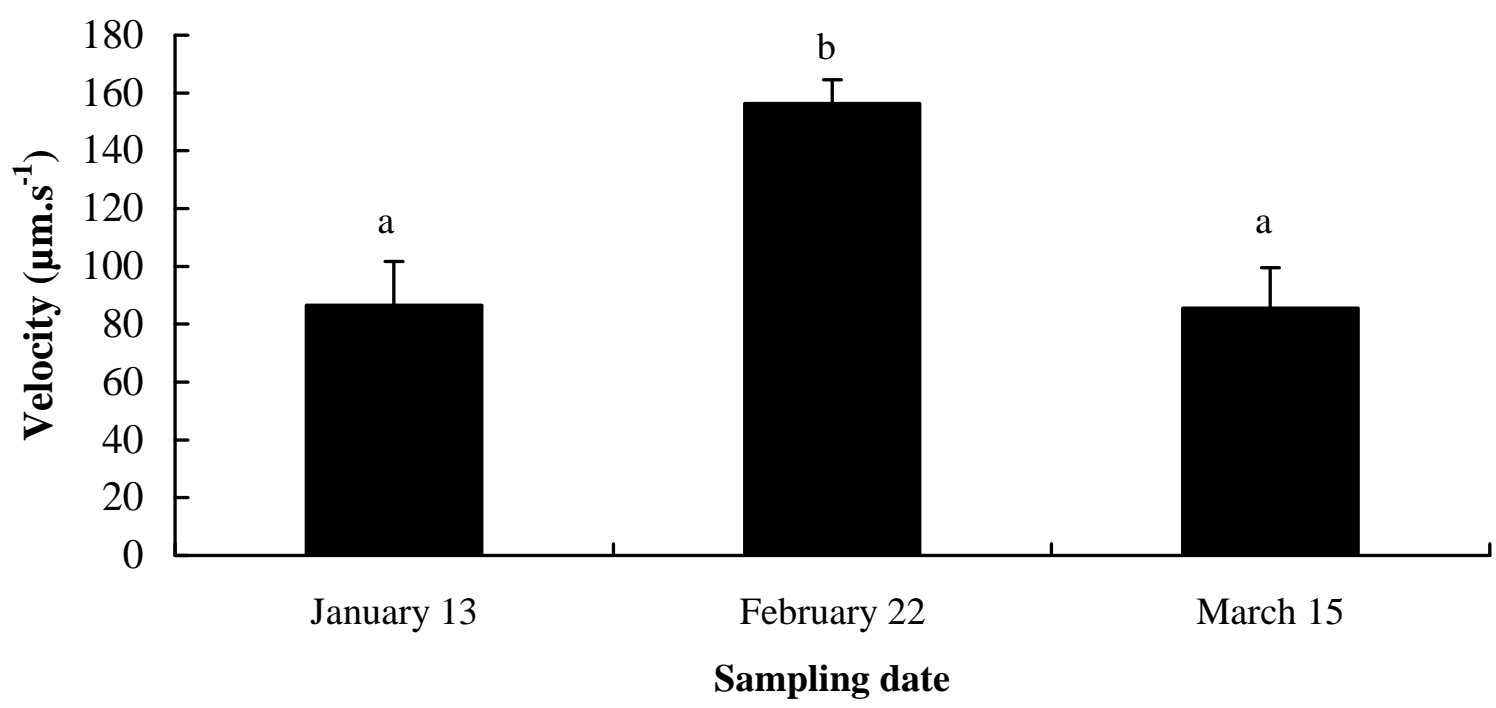

Fig. 7: Changes in sperm velocity during the spawning period (Different letters correspond to significantly different results, $n=7$ males). 

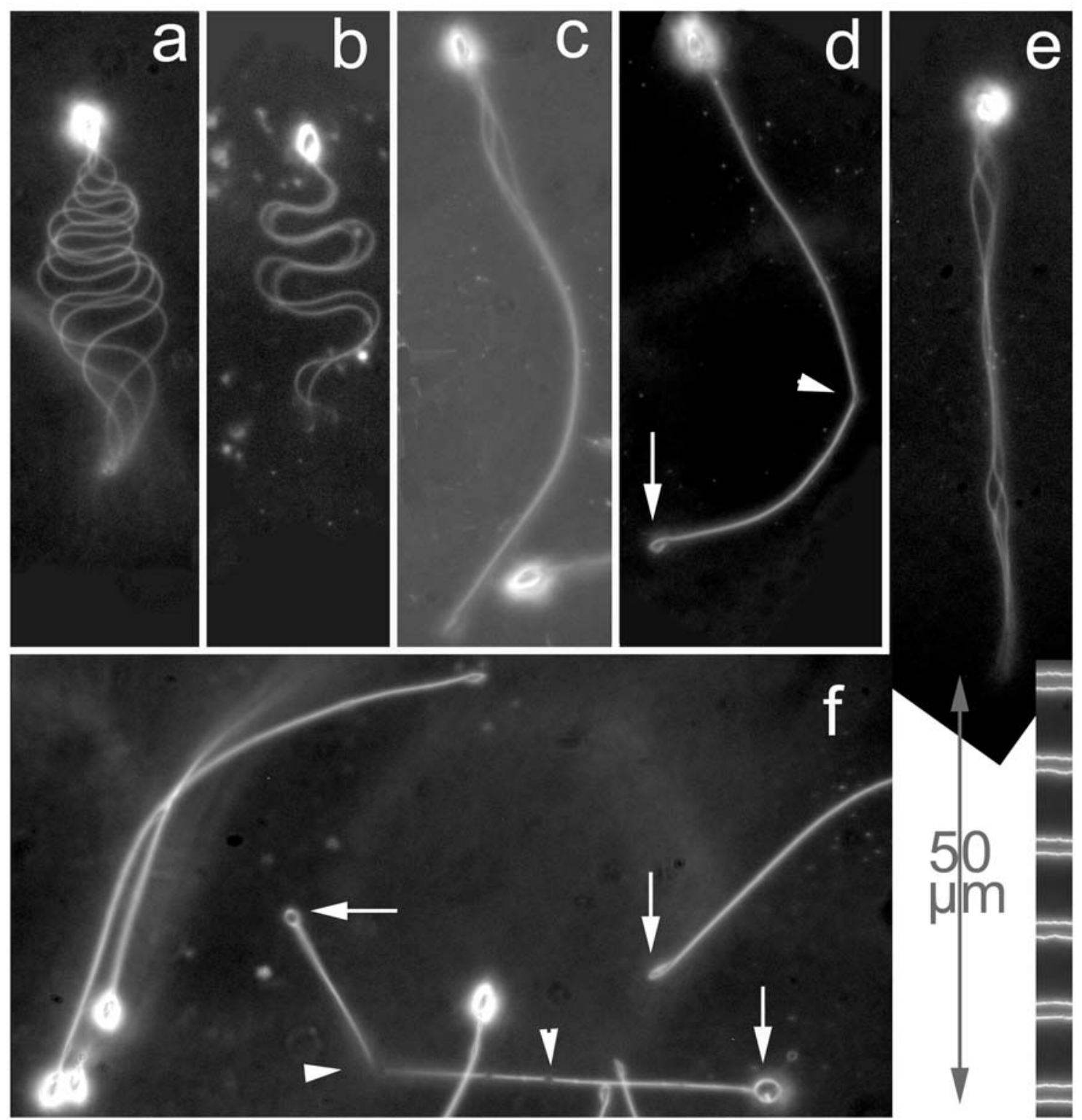

Fig.8: Examples of cell damages observed on cod spermatoza during medium or late periods of the spawning season after sperm activation (Pannels $\mathbf{a}, \mathbf{b}$ and $\mathbf{c}$ are from sperm cells collected during the medium part of the spawning period and show flagella with normal waves propagation ; pannels $\mathbf{d}$, e and $\mathbf{f}$ correspond to late period and show flagella devoid of waves propagation. Arrow heads in $\mathbf{d}$ and $\mathbf{f}$ pannels point to local blebs observed on the flagellum, leading to local and abnormal angle in the latter. Arrows point to loops appearing at the distal tip of the flagellum. In e, one can observe an abnormal situation with two regions of wave propagation. Bar scale on lower right $=50 \mu \mathrm{m}$. Photographies were obtained using stroboscopic illumination (5 microsec flashes) and dark field illumination with 40X magnification lens and show several positions of the flagellar wave propagation for motile spermatozoa. 
Table I. Changes in seminal fluid quality during the spawning season (Different letters correspond to significantly different results, $\mathrm{n}=10$ males).

\begin{tabular}{lllll}
\hline Parameter & January 13 & February 22 & March 15 & Statistics \\
\hline Osmotic pressure & $368.2 \pm 8.9^{\mathrm{a}}$ & $384.1 \pm 11.1^{\mathrm{b}}$ & $362.9 \pm 15^{\mathrm{a}}$ & $\mathrm{P}<0.01$ \\
pH & $7.87 \pm 0.17^{\mathrm{a}}$ & $8.05 \pm 0.26^{\mathrm{b}}$ & $8.41 \pm 0.21^{\mathrm{c}}$ & $\mathrm{P}<0.001$ \\
Protein $\left(\mathrm{mg} . \mathrm{ml}^{-1}\right)$ & $1.37 \pm 0.59^{\mathrm{a}}$ & $1.15 \pm 0.50^{\mathrm{ab}}$ & $0.94 \pm 0.42^{\mathrm{b}}$ & $\mathrm{P}<0.05$ \\
$\mathrm{Na}\left(\mathrm{mmol} . .^{-1}\right)$ & $183.1 \pm 15.1^{\mathrm{a}}$ & $196.7 \pm 10.1^{\mathrm{b}}$ & $186.7 \pm 11.9^{\mathrm{b}}$ & $\mathrm{P}<0.05$ \\
$\mathrm{Cl}\left(\mathrm{mmol} . .^{-1}\right)$ & $175.0 \pm 6.4^{\mathrm{ab}}$ & $179.3 \pm 6.1^{\mathrm{a}}$ & $171.0 \pm 7.2^{\mathrm{b}}$ & $\mathrm{P}<0.05$ \\
$\mathrm{Ca}\left(\mathrm{mmol} . .^{-1}\right)$ & $2.14 \pm 0.41^{\mathrm{a}}$ & $2.81 \pm 0.45^{\mathrm{b}}$ & $2.74 \pm 0.61^{\mathrm{b}}$ & $\mathrm{P}<0.001$ \\
$\mathrm{CO}_{2}\left(\mathrm{mmol} . \mathrm{I}^{-1}\right)$ & $8.6 \pm 1.7$ & $9.5 \pm 1.4$ & $9.8 \pm 2.0$ & $\mathrm{NS}$ \\
\hline
\end{tabular}

